conservation are, in fact, motivated by the need to clean up the mess of a former generation.

The case of Lake Baikal

A classic example of this is the case of Lake Baikal. This lake, the deepest in the world, has long been famous for its pure water and its extensive flora and fauna, with 708 unique types of living organisms, including freshwater seals. In Moscow News Gerasimov announced proudly, "It can be definitely said now that Lake Baikal will not die of pollution, as have many other lakes in the world". Under the Tsars, virtually the sole contact between Lake Baikal and the world of industry was the Trans-Siberian railway which skirted part of its southern shore. Inevitably, perhaps, the forests of the Baikal region came to be utilised, and the tributaries of the lake used for rafting timber prior to its further shipment down the Angara, Baikal's sole outlet. But the construction of cellulose and pulp mills in the unique habitat of Lake Baikal seemed odd in a system claiming to use natural resources "rationally" for the good of present and future generations.

The plans for the mills were approved in 1957 , but it was not until 1962 that the first authoritative protests began with an article in Komsomolskaya Pravda by the Director of the Limnological Institute of the Siberian Branch of the Soviet Academy of Sciences. Over the following decade, numerous similar articles were published, notably in Literaturnaya Gazeta and Priroda; Gerasimov himself was prominent in the campaign. Since campaigns of this nature in the State press (as opposed to the samizdat network) can only take place with tacit approval from Government bodies involved, there was either a high-level interdepartmental dispute over Lake Baikal or at least an effort to show official concern.

The indications are that there was opposition from the Academy of Sciences, the Geographical Society of the USSR, and the Expert Commission for the Coordination of Scientific Research. Nevertheless, under the auspices of the Ministry for Timber Production, the mills were built and began operation, discharging effluent into the lake. Even when effluent treatment installations were fully operational, the water discharged was yellowish and barely potable, and by no means comparable in quality with the original lake water. The only sound "economic" reason ever offered for the siting of the mills was the exceptional purity of the Baikal water-a purity needed for the production of certain high-quality products. As early as 1965, however, it was observed that water from the effluent outfall was being carried back by the current to the "pure" water inlet of the mills (Priroda, No. 11, 1965). Consequently it was necessary to process the intake water before use. This demanded the installation of expensive pre-treatment equipment the authorities had hoped to avoid by using Baikal water in the first place.

During the last five-year plan, considerable attention was devoted to the problem of the Baikal habitat. New legislation with Party backing was introduced in September 1971, and a special "emergency charter" was approved by the Ministry of Land Reclamation and Water Economy in November 1974. Timber-felling was forbidden within a radius of $50 \mathrm{~km}$ of the lake, and the tributaries of Baikal have been cleared of the sunken timber which might have absorbed much of the oxygen from the water and covered fish-breeding grounds; "very costly" outfall treatment plant has been installed at the cellulose mills, and whitefish hatcheries have been introduced to replenish depleted stocks.

Lake Baikal has always been of keen interest to ecologists throughout the world, but more recently it has attracted increased attention because of the construction of the Baikal-Amur Railway. Ecological restrictions relating to this at times verge on the absurd (workers must not spray mosquitoes with insecticide) or over-zealous (devastated areas from natural forest fires on the route are to be planted with seedlings, rather than left to regenerate naturally). But if all the recommendations are carried out, the future of Baikal is certainly assured, and the lake and its environs could well become an ecological show-place. The decision to admit American scientists to observe and participate in research on the lake suggests that already the worst hazards have been dealt with. which is gratifying. But the general question remains whether state ownership of resources entails their best use and protection.

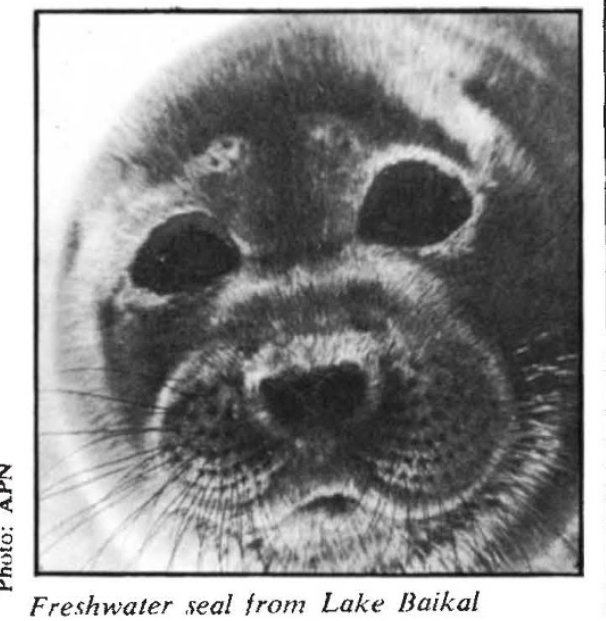

CANADA

SINCE the beginning of the year the outlook for Canadian science and technology for 1976 has not seemed a particularly optimistic one. The Ministry of State for Science and Technology, contrary to some predictions, did manage to survive the federal government's anti-inflation programme which killed off a number of other federal initiatives such as Information Canada, the Company of Young Canadians and Opportunities for Youth, and reduced others, such as the Local Initiatives Program. But the programme still means less money for science and technology generally.

Specifically, the Industrial Research and Development Incentives Act, which has provided between $\$ 20$ million and \$30 million a year for industrial research, will be repealed; reductions will be made in the Programme for Advancement of Industrial Technology and the Defence Industry Productivity Programme; and medical and other scientific research grants will be frozen.

The cuts were made in an attempt to prove to Canadians that the federal government was serious about fighting inflation. and that it intended to set an example. But since then the Prime Minister has gone further, telling the Canadian people that the anti-inflation measures are in fact attempts to control an economy that proved itself unable to work as a free market system-a remark that produced angry responses, including a call for an election by a former Progressive Conservative Cabinet minister

Altogether, the government said it would cut $\$ 1,500$ million from its future spending plans. The loss to scientific research funds was estimated at $\$ 14.8$ million and to industrial incentives at $\$ 8$ million. These are losses that the scientific community mostly regards as insupportable, in the light of the federal government's recent policies and the impact of inflation.

In a letter to the editor of the Toronto Globe and Mail, John Polanyi, Professor of Chemistry at the University of Toronto, pointed out that the total funds available to the National Research Council (NRC), the chief funding hody for fundamental research in Canada, will have increased at an average rate of only $2.5 \%$ a year from 1969 to 1977 , while the cost of doing research during the same period had increased by $100 \%$.

The NRC grants committees, on which he has served, "are quite unable to keep existing research projects of high promise moving ahead. while at the same time giving a genuine opportunity to the scientists of tomorrow to prove their mettle". And, he went on, 
"our neglect of science is something that sets us clearly apart from countries with which we might reasonably compare ourselves. In the United States, in France, in Germany, even in beleaguered Britain, the support of basic science has roughly kept pace with inflation. Only in Canada has inflation been used, year after year, as a device for diminishing the nation's investment in this fundamental activity."

In a letter to the same newspaper, Dr Gordon Forstner said that in medical research "somewhere between 150 and 300 technicians will lose their jobs, and a programme which has been deflated steadily during the last five years will be shattered."

- In such a climate, it was with mixed feelings that some Canadians heard that the heavy water plant at Glace Bay, Nova Scotia, was starting up and would shortly produce heavy water not only for nuclear reactors in Ontario and Quebec but also for those in Britain, Argentina and South Korea. Although heavy water is vital to Canada's CANDU reactors (in which it acts as coolant and moderator), the Glace Bay plant has been one of the most disastrous undertakings of an otherwise successful nuclear programme.

In 1964, the province of Nova Scotia brought in a US nuclear scientist, Jerome Spevack, to design the Glace Bay plant. There were difficulties from the outset. Completion was delayed from 1966 to 1967 , then again to 1969 . Technical difficulties occurred as a result of using salt water from the nearby Atlantic Ocean in the process, instead of fresh water. Finally, in 1970, inspectors discovered that the salt water had corroded the pipes, and a $\$ 30$ million repair was needed.

By that time, Spevack's company, Deuterium of Canada Ltd, had spent $\$ 100$ million on the plant, all of it public money, because Nova Scotia was the major shareholder and provided the finance. The province had bought out Spevack's interest for $\$ 3$ million in 1966, and taken full control in 1969. In 1971, the federal government provided the funds for the plant's purchase by Atomic Energy of Canada Ltd (AECL), and spent another $\$ 130$ million on what has been almost a complete reconstruction.

Eventually, the plant is expected to become self-sustaining and make enough money to pay back AECL's investment. The Nova Scotia government is to get the plant back after AECL has recouped its investment, but the province plans them to sell it back once more to AECL-finally washing its hands, as it were, of the whole affair.

David Spurgeon

Ottawa

USA

\section{Alternative technologies urged in pesticide report}

Carried to excess, the best things may do more harm than good. Colin Norman reports from Washington on a study of pesticides.

A commitTeE of the National Academy of Sciences has warned, in a mammoth study published last week, that unless alternatives to conventional chemical pesticides are swiftly developed and adopted, agricultural production in the United States could soon begin to suffer. The committee bases that conclusion on the fact that several potent products have been either severcly restricted or banned entirely because of environmental and health hazards, and also the fact that several pests are developing resistance to the poisons which are sprayed on them in copious quantities each year.

The study, which took more than three years to complete and which runs to five massive volumes, is an attempt to assess the current state of the art in pest control and to pinpoint some of the problems which lie ahead. In the course of its analysis, the committee has questioned the costs of some government regulations, criticised current pest control practices, cast doubt on the value of some of the Department of Agriculture's most ambitious and costly efforts to eliminate particular insect species and, by implication, criticised the federal government's agricultural research efforts.

The basic theme running through the huge tome is that although chemical pesticides have served agricultureand, for that matter public health pro- grammes-very well, the problems of declining effectiveness "warrant substantial expansion of present efforts to promote alternative technologies, including integrated pest management". The chairman of the committee, Dr Donald Kennedy, professor of physiology and zoology at Stanford, said last week, for example, that genetic resistance to toxic pesticides is growing at an "alarming rate", and he suggested that unless effective alternatives are developed, some agricultural land could conceivably be taken out of production.

As for specific alternatives, the committee notes that so-called 'third generation' compounds, which affect hormonal development or reproductive processes in insects, have some desirable qualities, but it suggests that "there is reason to be pessimistic about the prospects for controlling major crop pests with these compounds." One potential problem with third generation agents is that resistance is likely to develop to them, the committee states.

Insect control by pathogens, such as bacculoviruses, is especially promising, but the committee cautions that largescale use of such agents will require improved methods for culturing insect host tissues. Moreover, the development of new agents will require some advances in basic research. The use of genetic techniques, such as breeding resistance to pests into crop plants, and introducing genetically modified pests into the environment, are also promising, but again the committee

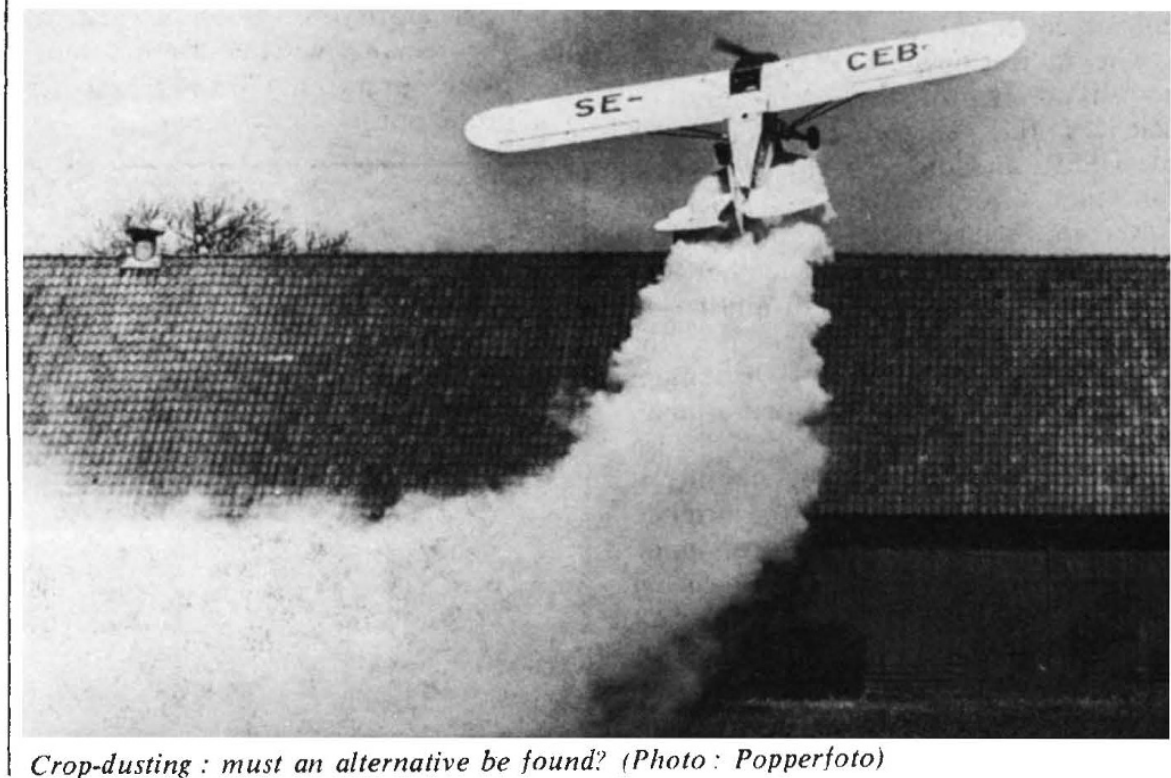

